\title{
The study of the zoobenthos of the Tsraudon river basin (the Terek river basin)
}

\author{
Ia E. Dzhioeva*, Susanna K. Cherchesova, Oleg A. Navatorov, and Sofia F. Lamarton \\ North Ossetian state University named after K.L. Khetagurov, Vladikavkaz, Russia
}

\begin{abstract}
The paper presents data on the species composition and distribution of zoobenthos in the Tsraudon river basin, obtained during the 2017-2019 research. In total, 4 classes of invertebrates (Gastropoda, Crustacea, Hydracarina, Insecta) are found in the benthic structure. The class Insecta has the greatest species diversity. All types of insects in our collections are represented by lithophilic, oligosaprobic fauna. Significant differences in the composition of the fauna of the Tsraudon river creeks and tributary streams have been identified. 7 families of the order Trichoptera are registered in streams, and 4 families in the river. It is established that the streamlets of the family Hydroptilidae do not occur in streams, the distribution boundary of the streamlets of Hydropsyche angustipennis (Hydropsychidae) is concentrated in the mountain-forest zone. The hydrological features of the studied watercourses are also revealed.
\end{abstract}

\section{Introduction}

The biocenoses of flowing reservoirs of the North Caucasus, and especially small rivers, remain insufficiently explored today; particularly, there is no information about the systematic composition, biology and ecology of amphibiotic insects (mayflies, stoneflies, caddisflies and dipterous) of the studied basin. Amphibiotic insects are an essential link in the food chain of our reservoirs and at the same time can be attributed to reliable indicators of water quality. In this regard, a comprehensive study of mountain streams and, in particular, small rivers is a very important tool for biomonitoring, on the basis of which we can judge both the state of a particular watercourse and the river network as a whole. Small rivers are a source of drinking water, and they are unique refugium's of amphibious fauna. The diversity of amphibiotic communities is a guarantee of the stability of aquatic ecosystems. With such a sensitive tool for long-term monitoring, we can judge about the well-being of the watercourse based on the numerical changes in zoobenthos groups and their species composition. One interesting waterways in the study of dynamics of communities of zoobenthos, is a small river Tsraudon (the Terek river basin).

\footnotetext{
* Corresponding author: cherchesova $@$ yandex.ru
} 


\section{Materials and methods}

The paper presents the results of research carried out by us in the basin of the river Tsraudon in the 2017-2019. Data on the hydrology and composition of amphibiotic insects of the Tsraudon river were given earlier [1,2]. In this paper, we consider the species composition of amphibiotic insects of the Tsraudon river basin (the Tsraudon river and its tributary streams). When comparing the fauna of streams and the river Tsraudon, we rely on the data of the above-mentioned work. During the research, 5 stations were installed in various altitude zones (from $550 \mathrm{~m}$ above sea level to $1300 \mathrm{~m}$ above sea level). In total, more than 2000 specimens of amphibiotic and aquatic insects, as well as representatives of related fauna (Crustacea, Mollusca, Turbellaria, Hydracarina) were collected.

\section{Results}

The Tsraudon river is a typical small river of the Terek basin [1, 4], which flows in the mountainforest and foothill zones of the Republic. The river is fed by underground water and rain. In the mountainous part of the basin-the river is transparent, the rocky bottom is composed of large boulders and pebbles of light rocks. The speed of water flow in this section, which passes in the mountain forest, where valuable tree species are concentrated (beech, hornbeam, birch) is $1.5 \mathrm{~m} / \mathrm{s}$, the depth of the stream reaches $0.3-0.5 \mathrm{~m}$. spring and summer floods are typical for the watercourse. On the foothill section, the flow depth is $0.1-0.3 \mathrm{~m}$, the water transparency is reduced, and the water flow rate is reduced to $0.5-1.0 \mathrm{~m} / \mathrm{sec}$. During the period of snowmelt (mayjune) and heavy rains (late may - mid - july), the river becomes mudslide-the flow speed during this period is $5-7 \mathrm{~m} / \mathrm{sec}$. Tributary streams also flow in mountain-forest and foothill zones, they are characterized by the following indicators: flow rate $-0.4-1.2 \mathrm{~m} / \mathrm{s}$, depth $-0.1-0.3 \mathrm{~m}$, water consumption $0.1-0.9 \mathrm{~m}^{3} / \mathrm{s}$. In hot summer and winter, the water in the streams becomes shallow and often dries up, and during heavy rains the water level in the streams reaches critical values. The water temperature in summer ranges from $8{ }^{\circ} \mathrm{C}$ to $12^{\circ} \mathrm{C}$. The bottom of the streams is stony with sandy and muddy scythes, along the banks there are thickets of blackberries, raspberries, elderberries, hazel, there are walnut plantings.

As a result of cameral processing of the material, we have established 5 classes for the Tsraudon river basin: Gastropoda, Turbellaria, Crustacea, Arachnida and Insecta. The leading role in the structure of zoobenthos is played by insects (Insecta) - 96\%, represented by 4 orders, 19 families and 42 species. All other representatives of zoobenthos (Mollusca, Turbellaria, Amphipoda, Hydracarina) make up $4 \%$ of all gathers.

\section{Discussion}

As mentioned above, in the structure of the zoobenthos of the Tsraudon river basin, the most numerous is the class Insecta, which unites 4 orders (Ephemeroptera, Plecoptera, Trichoptera and Diptera). The order Ephemeroptera is represented by 5 families and 11 species: Ephemerellidae (1), Baetidae (3), Heptageniidae (5), Oligoneuriidae (1), Caenidae (1). The order Trichoptera is represented by 6 families and 12 species: Rhyacophilidae (3), Hydropsychidae (4), Glossosomatidae (1), Apataniidae (1), Lepidostomatidae (1), Limnephilidae (2), and Hydroptilidae (1). The order Plecoptera includes 5 families and 13 species: Perlidae (2), Perlodidae (1), Nemouridae (5), Taeniopterygidae (2), Capniidae (1), and Leuctridae (2). The order Diptera is mainly represented by 3 families and 6 species: Chironomidae (2), Simuliidae (3), Blepharoceridae (1).

In addition to the representatives of the insect class, the structure of zoobenthos includes gastropods, amphipods, planarians, and aquatic mites, which are significantly inferior both in numbers and in species diversity to the insect class (Fig. 1, 2). 


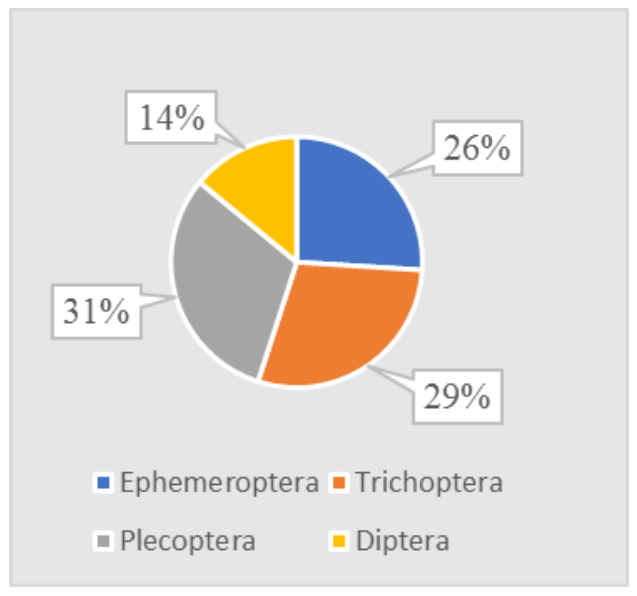

Fig. 1. Taxonomic ratio of orders of the class insects

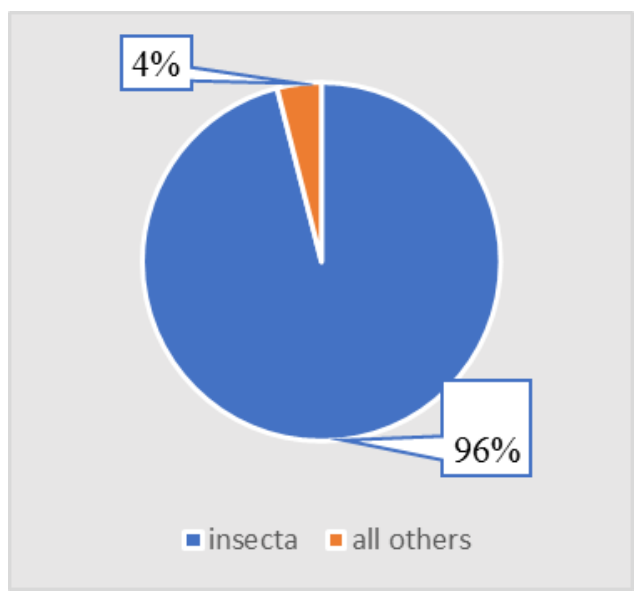

Fig. 2. Percentage of insects and other representatives of zoobenthos

The fauna of tributary streams differs from that of rivers by the predominance of representatives of the order Trichoptera, for the development of which the stability of the biotope and temperature regime are favorable. There are 7 families registered here: Rhyacophilidae, Hydropsychidae, Glossosomatidae, Philopotamidae, Limnephilidae, Lepidostomatidae, Apataniidae, which make up $74 \%$ of the total mass of benthic streams. Only 4 families (Rhyacophilidae, Hydropsychidae, Glossosomatidae and Hydroptilidae) have been recorded for the Tsraudon river. The density of caddisflies in streams is quite high (more than $1000 \mathrm{copies} / \mathrm{m}^{2}$ ). The dominant species in the streams of the basin are: Glossosoma capitatum Mart., Pothamophylax latipennis Curt., rare ones are: Dinarthrum longiplicatum Mart.

The difference in species composition of the river fauna is the dominance of benthos species of caddisflies of the family Hydropsychidae (it should be noted that the species $H$. angustipennis Curt. is distributed only in the mountain-forest zone), in spring there are a lot of Hydroptilidae caddisflies in the Tsraudon river (in the streams-tributaries of the pool family Hydroptilidae are not registered). 


\section{Conclusion}

Comparing the features of the faunas of streams and rivers, it should be noted that typical stream species are: Wormaldia subnigra McL. (rare in our collections); Pothamophylax latipennis Curt., Limnephilus extricates VcL., Dinarthrum longiplicatum Mart.; species from the families Rhyacophilidae, Glossosomatidae, Hydropsychidae are found in the river and in the streams; the family Hydroptilidae in our collections - numerous, spring typical river view.

Zoogeographic composition of trichopteran fauna: Agapetus oblongatus Mart. - endemic to the Caucasus; G. capitatum Mart., D. longiplicatum Mart. - subendemic; H. sciligra Mal. - Central Asian; R. fasciata Hag., W. subnigra McL., H. angustipennis Curt. - European; $R$. nubile Zett., $H$. contubernalis McL., P. latipennis Curt. - Palearctic.

Ecology of species: issues of ecology of amphibiotic insects living in small rivers were discussed earlier $[3,5,6]$. the analysis of the fauna of amphibiotic insects of the river Tsraudon and streams-tributaries of the studied basin showed that the larvae of mayflies, caddisflies, stoneflies and dipteran live in the surveyed reservoirs all year round. Biotopes of collected larvae are typical mountain streams with a high flow rate, and clear water, summer temperature is 12 $14^{0} \mathrm{C}$.

Thus, the main faunal core of hydro biocenoses of the Tsraudon river basin is represented by oligosaprobic, stenothermic and litophilous fauna.

\section{References}

1. Kornoukhova I.I., Cherchesova S.K. Fauna and ecology of animals of the Caucasus, 41-45 (Ordzhonikidze, 1987)

2. Cherchesova S.K. Amphibiotic insects (Ephemeroptera, Plecoptera, Trichoptera) of the rivers of North Ossetia (Moscow, 2004)

3. Tsibirova L.L., Khablieva A.A., Kompantsev A.A., Cherchesova S.K. Bulletin of Tambov University. Series: Natural and technical Sciences, 22(5-1), 1031-1034 (2017)

4. Phallagova Dz.M. Proceedings of the Institute of the History, Economics and Literature (Ordzhonikidze, 1973)

5. Cherchesova S.K. Proceedings of the Russian State Agrarian University - Moscow Timiryazev Agricultural Academy, 3,182-189 (RSAU, Moscow, 2002)

6. Cherchesova S.K., Tuaeva S.R., Kornoukhova I.I. Proceedings of Gorsky State Agrarian University, 52(4), 385-390 (2015) 